\title{
FURTHER EVIDENCE FOR APOSTATIC SELECTION BY WILD PASSERINE BIRDS: TRAINING EXPERIMENTS
}

\author{
JOHN A. ALLEN* \\ Deportment of Zoology, University of Edinburgh
}

Received 12.iii.74

\begin{abstract}
Summary
Sight-dependent predators may tend to form " searching images " for common varieties of a polymorphic prey species. Selection would then be frequencydependent and could maintain the polymorphism. This hypothesis has been tested in 13 experiments by presenting populations of green and brown lardand-flour " baits" to wild passerine birds in their normal surroundings. In each experiment groups of birds were "trained" on greens or browns and were then exposed to populations with the two colours in equal proportions. In every case there was a highly significant tendency for the familiar colour to be taken in excess. In three of the experiments the birds were given a second period of training, this time with the unfamiliar colour. Their overall preferences were reversed and the effect of the training seemed to decrease with time.
\end{abstract}

\section{INTRODUGTION}

IT has been suggested that sight-dependent predators are capable of actively maintaining non-mimetic colour polymorphisms in their prey (Poulton, 1884; Cain and Sheppard, 1954; Haldane, 1955; Clarke, 1962a; Moment, 1962). They tend to concentrate their search on the common morphs and correspondingly overlook the rare ones. The selective value of a given morph is then inversely related to its frequency in the population, a relationship which is known to maintain genetic polymorphism (Wright, 1948; Li, 1962; Haldane and Jayakar, 1963; Clarke and O'Donald, 1964). Clarke (1962a) has described such selection as being "apostatic", because it favours "apostates" or visually distinct deviants from the norm. As support for the hypothesis he drew on his own work (Clarke, 1962b) with the European landsnails Cepaea nemoralis and Cepaea hortensis, species which have essentially homologous polymorphisms for shell ground colour and banding. Clarke considered the situation where apostatic selection is acting on a mixed colony of the two species of Cepaea and reasoned that if a particular morph is common in one species (for causes unrelated to its visual properties) then the same morph would be prevented from reaching a high frequency in the other species. Negative correlations of morph frequency would therefore be predicted and Clarke $(1962 a, b)$ presented data which seemed to agree with this expectation, a claim that has since been questioned by Carter (1967) and defended by Clarke (1969). Discussion of this controversy is outside the scope of the present paper.

\section{Behavioural eVidence for apostatic Selection}

The hypothesis of apostatic selection assumes that predators are most likely to form "specific searching images" (von Uexkull, 1934; Tinbergen,

* Present address : Department of Zoology, P.O. Box 35064, University of Dar es Salaam, Dar es Salaam, Tanzania, E. Africa. 
1960) for common varieties of prey (Clarke, 1962a). "Searching image" was first put into an ecological context by Tinbergen (1960) when he used the term to explain a certain change in the behaviour of titmice (Parus spp.) when hunting insect prey in pine forests. He found that when a particular prey became abundant there was usually a lag of a few days before it appeared in substantial numbers in the birds' diet. Tinbergen proposed that chance encounters with the new prey led to an improvement in the birds' ability to perceive it and he called this process " adoption of a searching image". An important property of the searching image is that it is capable of effecting a choice which is contrary to innate and other " unlearned" preferences (Croze, 1970). Dawkins (1971a) has recently criticised the term because it has been used to describe more than one type of change of feeding behaviour. I shall use the phrase " adopting a searching image " in the original sense of von Uexkull (1934) and Tinbergen (1960), where the stress is on the perceptual aspect of the behaviour.

Tinbergen's (1960) work is quoted by Clarke (1962a) as support for apostatic selection. However, although Tinbergen's data have received some confirmation (e.g. by Mook et al., 1960; Gibb, 1962), his interpretation that the birds were hunting by searching image has been questioned on the grounds that they were probably seeking areas where the prey were most dense (Royama, 1970, but see Croze, 1970; Smith and Dawkins, 1971). Clarke also gleans evidence for apostatic selection from work with captive fish as predators: Reighard's (1908) data for grey snappers (Lutianus griseus) feeding on dyed sardines (Atherina laticeps), and Popham's (1941, 1942) data for rudd (Scardinius eryophthalmus) preying on corixid bugs (Arctocorisa distincta). Reighard's results seem to show that the fish were hunting by searching image but unfortunately the experimental design does not exclude the possibility that the predators were selecting on the basis of " unlearned" colour preferences (Croze, 1970). A re-analysis of Popham's data (Clarke, $1962 a$ ) suggested that the rudd concentrated on the common varieties in a polymorphic " population" of corixid bugs. However, Popham's results were obtained from only a small number of individual predators and, in addition, Popham himself showed that the varieties of the corixids differed in their behaviour.

The last 10 years have seen the steady accumulation of further evidence for apostatic selection. Some of it is indirect and comes from considerations of the possible relationship between apostatic selection and the density and degree of polymorphism of the prey population (Owen, 1963; Greenwood, 1969; Smith, 1971). Other support stems from observations of predators when feeding on mixed "populations" of different species (Murdoch, 1969); " populations" of artificial polymorphic prey (Allen and Clarke, 1968; Croze, 1970; Oates, quoted by Cook, 1971; Murton, 1971; Manly et al., 1972); and populations of natural polymorphic prey (den Boer, 1971; Arnold, unpublished).

In one attempt to test the hypothesis of apostatic selection, wild passerine birds in their normal surroundings were offered "populations" of green and brown lard-and-flour prey (Allen and Clarke, 1968). We approached the problem in two ways. In one, a group of birds was " trained" on one morph alone before being offered a population with the two colours in equal numbers. The results from the " $1: 1$ " populations suggested that the birds had acquired searching images for the familiar colour, that the 
tendency to search for this colour decreased with time, and that the preference could be reversed by a period of training with the unfamiliar colour.

This paper presents data from experiments of the type just described. A companion article (Allen, 1974) deals with the second approach to testing apostatic selection, in which untrained groups of birds were presented populations with one colour nine times as common as the other. The two sets of experiments form part of a larger investigation into apostatic selection (Allen, 1972) and the results confirm the findings of the original paper (Allen and Clarke, 1968).

\section{General materials and methods}

(i) Prey

The prey were green and brown cylindrical " baits", $0.7 \mathrm{~cm}$ long $\times 0.7$ $\mathrm{cm}$ wide. Scored by the Munsell Book of Color (1966) the greens had a hue of $7.5 \mathrm{GY}$ and a Value/Chroma of $7 / 10$, while the browns had a hue of 5 YR and a Value/Chroma of 6/6. Green and brown were chosen originally because it was believed that they are colours representative of natural palatable prey. Furthermore, polymorphism in terrestrial species is often based on these two colours e.g. in lepidopteran larvae (Poulton, 1884); the nymphs and imagos of grasshoppers (Owen, 1966; Byrne, 1967); tree frogs (Resnick and Jameson, 1963; Schiøtz, 1971); and chameleons (Ogilvie and Owen, 1962).

The baits were made from plain flour ("Snowy Mountain") and lard ("White Cap") in a $5: 2$ ratio by weight (after Turner, 1961). The mixture was kneaded to a dough of "plasticine"-like consistency and artificial food dyes (varieties "green" and "brown", supplied by the Scottish Colour and Flavour Company) were then added, approximately $11 \mathrm{cc}$ of dye per $1000 \mathrm{gm}$ of dough giving the required colours. When the dough was uniformly coloured it was forced by hand through circular holes in a sheet of " perspex". The long "worms" that were formed were laid side-by-side and simultaneously chopped into $0.7 \mathrm{~cm}$ sections which were stored in plastic boxes at room temperature.

\section{(ii) Presentation of prey populations}

At some stage in each experiment a population of randomly distributed baits was presented at a density of two per square metre and the method of establishing such a population was as follows:

\section{Experimental plot}

The population was contained in a square or rectangular grid of 1-metre squares marked by metal or wooden skewers. To allow identification of each metre square the columns and rows were respectively numbered and lettered by cards placed around the perimeter and, in some cases, along the middle lines. Physical and practical factors determined the size of the plot; in the training experiments it was generally 251 -metre squares, corresponding to a population size of 50 baits.

\section{Randomisation of prey distribution}

The randomness of the distribution of the baits was an important component of the experimental system and the methods by which it was attained merit discussion. The first stage was to make " mimeo" copies of the grid, 
with each metre square divided into four quadrants. These copies were used to record the distributions of future populations. The next step was to randomise the baits with respect to position. Random number tables (Fisher and Yates, 1963) were used to determine the quadrant into which the two baits of each metre square were to be placed-they were never placed in the same quadrant. The third stage was to compute their distribution with respect to colour. In the early experiments this was done with random numbers, but later, playing cards were used.

During the preliminary experiments (Allen and Clarke, 1968) it was realised that the plots may not be searched uniformly by the birds; some of them may, for instance, prefer one particular corner. These birds would then be most often exposed to the morph frequency within this area and this might differ from the proportion within the population as a whole. In order to minimise the possibility of appreciable differences in morph frequency between different areas, later populations were divided into four equal parts with identical frequencies of the two colours.

To eliminate bias in the positioning of the baits with respect to ground cover, they were dropped into their appropriate quadrants from waist height. Further randomisation was added by frequently changing the distribution. This was usually carried out daily and helped to prevent the birds from learning the positions of the baits.

\section{(iii) Recording the data}

Each population was observed from appropriate cover, for example, a house or a motor car. Binoculars $(8 \times 30)$ were essential. When a bird entered the plot, events were recorded in the following order:

(a) Time of entry.

(b) Species and, if possible, sex and individual recognition marks.

(c) Position of eaten baits. A bait was defined as "eaten" if all or part of it was removed. Baits which were disregarded and baits which were simply picked up and then dropped leaving an imprint of the beak were defined as " uneaten". The number of the two colours eaten were thus recorded, as was the sequence in which they were eaten.

(d) Other points of interest regarding the birds' behaviour.

(e) Time of departure. This was difficult to record accurately when more than one bird was feeding.

With practice two or more birds could be observed simultaneously, but when too many were involved only a few selected individuals could be followed. The overall numbers taken by the rest were deduced from an examination of the plot. Frequent replacement of eaten baits ensured that the ratio of the two colours was kept constant.

\section{(iv) Birds}

In common with other experiments (Allen, 1972) the present ones were dominated by the blackbird, Turdus merula (for its general habits see Snow, 1958). This was always the first and in most cases the only species to feed on the baits. Other species encountered were: housesparrows (Passer domesticus), dunnocks or hedgesparrows (Prunella modularis) and robins (Erithacus rubecula). 


\section{EXPERIMENTS}

(i) Plan

Thirteen training experiments have been carried out: a preliminary experiment (Allen and Clarke, 1968), details of which are reiterated here, and three series of repeat experiments. In outline, the experiments were planned as follows:

\section{Preliminary experiment}

Late summer 1966. Birds were trained on greens and then presented with a "1 : 1" population.

After a lapse of 1 month, training was repeated with browns, after which the birds were again exposed to a " 1 : l " population.

\section{Repeat experiments}

Series 1. Winter 1967. Four experiments at separate sites. At two, birds were trained on browns and at the other two, on greens, before being presented with a "1:1" population.

Series 2. Early Spring 1969. Six experiments at different sites. Three were "brown-trained" and three were "green-trained" before the presentation of " $1: 1$ " populations.

Series 3. Winter 1969. Two experiments at separate sites. In one, birds were fed on green baits and were then exposed to a " $1: 1$ " population. They were then trained on browns and again offered a " $1: 1$ " population. The second experiment was the same, except that browns were used in the first training session and greens in the second.

\section{(ii) Procedures}

The experiments took place near Edinburgh and their sites (nearest farms or villages) and O.S. grid references are given in table 1 . The populations of the preliminary experiment were presented on a background of dark soil marked out in a rectangular grid of 401 -metre squares. In the repeat experiments the background was grass and each plot consisted of a square of 25 l-metre squares situated near the perimeter of an agricultural field, where nearby hedges and trees provided cover for potential predators.

In all experiments training was completed by scattering the plot with baits of the appropriate colour every day for about a week. Approximately 2000 baits were consumed at each site. Populations with equal numbers of the two colours were presented on the day following the end of the period of familiarisation. In the preliminary experiment such " $1: 1$ " populations were presented for 3 days after the first training session and for 1 day after the second. The experiments of series 1 and 2 both involved 1 day's presentation of a " $1: 1$ " population, while in the experiments of series 3 the training sessions were each followed by 3 days' presentation of a " $1: 1$ " population. Table 2 gives the actual dates of the training periods and presentation of the " $1: 1$ " populations.

Blackbirds were the sole predators in 11 experiments. In the preliminary experiment housesparrows, dunnocks and robins ("small birds") were also involved, as were housesparrows in experiment 2.3. On these occasions 
TABLE 1

Sites of repeat training experiments, giving nearest farms or villages and Ordnance Survey grid references. All the sites were in grass fields in Midlothian, Scotland

\begin{tabular}{|c|c|c|c|c|}
\hline \multirow[b]{2}{*}{$\begin{array}{l}\text { Preliminary } \\
\text { experiment }\end{array}$} & \multicolumn{2}{|r|}{ Brown-trained } & \multicolumn{2}{|r|}{ Green-trained } \\
\hline & Expt. & $\begin{array}{l}\text { Site } \\
\text { (as }(a))\end{array}$ & $\underset{(a)}{\text { Expt. }}$ & $\begin{array}{l}\text { Dalkeith } \\
\text { NT } 352678\end{array}$ \\
\hline \multirow[t]{2}{*}{ Series 1} & 1.1 & $\begin{array}{l}\text { Dryden Mains, Roslin } \\
\text { NT } 275643\end{array}$ & 1.2 & $\begin{array}{l}\text { Broomhills, Burdiehouse } \\
\text { NT } 268672\end{array}$ \\
\hline & 1.3 & $\begin{array}{l}\text { Capielaw, Rosewell } \\
\text { NT } 302617\end{array}$ & 1.4 & $\begin{array}{l}\text { Dalhousie Chesters, } \\
\text { Rosewell } \\
\text { NT } 303637\end{array}$ \\
\hline \multirow[t]{3}{*}{ Series 2} & 2.1 & $\begin{array}{l}\text { Liberton } \\
\text { NT } 261702\end{array}$ & 2.2 & $\begin{array}{l}\text { Dryden Mains, Roslin } \\
\text { NT } 274642\end{array}$ \\
\hline & $2 \cdot 3$ & $\begin{array}{l}\text { Broomhills, Burdiehouse } \\
\text { NT } 268673\end{array}$ & 2.4 & $\begin{array}{l}\text { Hillend } \\
\text { NT } 255667\end{array}$ \\
\hline & 2.5 & $\begin{array}{l}\text { Upper Dalhousie } \\
\text { NT } 308635\end{array}$ & $2 \cdot 6$ & $\begin{array}{l}\text { Thornton } \\
\text { NT } 291610\end{array}$ \\
\hline \multirow[t]{2}{*}{ Series 3} & $3.1 a$ & $\begin{array}{l}\text { Capielaw, Rosewell } \\
\text { NT } 302617\end{array}$ & $3.1 \mathrm{~b}$ & (as 3.1a) \\
\hline & $3.2 b$ & (as 3.2a) & $3.2 \mathrm{a}$ & $\begin{array}{l}\text { Liberton } \\
\text { NT } 272704\end{array}$ \\
\hline
\end{tabular}

TABLE 2

Inclusive dates of training and presentation of $1: 1$ populations in training experiments. In the preliminary experiment and experiments 3,1 and 3.2 the order of presentation of the " $1: 1$ " populations is indicated by the postscripts (a) and (b) and the arrows

\begin{tabular}{|c|c|c|c|c|c|c|}
\hline \multirow[b]{3}{*}{$\begin{array}{l}\text { Preliminary } \\
\text { experiment }\end{array}$} & \multicolumn{3}{|c|}{ Brown-trained } & \multicolumn{3}{|c|}{ Green-trained } \\
\hline & \multirow{2}{*}{$\begin{array}{l}\text { Expt. } \\
(b)\end{array}$} & $\begin{array}{l}\text { Dates of } \\
\text { training }\end{array}$ & $\begin{array}{c}\text { Dates of } \\
\text { presentation } \\
\text { of " } 1: 1 \text { " pops }\end{array}$ & \multirow{2}{*}{$\begin{array}{l}\text { Expt. } \\
\leftarrow(a)\end{array}$} & \multirow{2}{*}{$\begin{array}{c}\text { Dates of } \\
\text { training } \\
31 \cdot 8 \cdot 66- \\
5.9 .66\end{array}$} & \multirow{2}{*}{$\begin{array}{c}\text { Dates of } \\
\text { presentation } \\
\text { of " } 1: 1 \text { " pops } \\
6 \cdot 9 \cdot 66 \text { - } \\
8.9 .66\end{array}$} \\
\hline & & $\begin{array}{l}10 \cdot 10 \cdot 66- \\
15.10 .66\end{array}$ & $16 \cdot 10 \cdot 66$ & & & \\
\hline Series 1 & 1.1 & $\begin{array}{l}12.11 .67- \\
18.11 .67\end{array}$ & 19.11 .67 & 1.2 & $\begin{array}{l}13.11 .67- \\
19.11 .67\end{array}$ & 20.11 .67 \\
\hline \multirow{3}{*}{ Series 2} & 1.3 & $\begin{array}{c}30.11 .67- \\
6.12 .67\end{array}$ & 7.12 .67 & 1.4 & $\begin{array}{c}8.12 .67- \\
15.12 .67\end{array}$ & 16.12 .67 \\
\hline & 2.1 & $\begin{array}{c}4.3 .68- \\
10.3 .68\end{array}$ & 11.3 .68 & 2.2 & $\begin{array}{c}4.3 .68- \\
10.3 .68\end{array}$ & 12.3 .68 \\
\hline & 2.3 & $\begin{array}{c}9.3 .68- \\
15.3 .68\end{array}$ & 16.3 .68 & 2.4 & $\begin{array}{l}19.3 .68- \\
25.3 .68\end{array}$ & 26.3.68 \\
\hline \multirow{3}{*}{ Series 3} & 2.5 & $\begin{array}{l}18.3 .68- \\
24.3 .68\end{array}$ & 25.3.68 & 2.6 & $\begin{array}{l}24.3 .68- \\
30.3 .68\end{array}$ & 31.3 .68 \\
\hline & $3.1 a$ & $\begin{array}{l}20.11 .69- \\
27.11 .69\end{array}$ & $\begin{array}{l}28.11 .69- \\
30.11 .69\end{array}$ & $\rightarrow 3.1 b$ & $\begin{array}{c}31.11 .69- \\
6.12 .69\end{array}$ & $\begin{array}{l}7.12 .69- \\
8.12 .69\end{array}$ \\
\hline & $3.2 b$ & $\begin{array}{l}13.12 .69- \\
18.12 .69\end{array}$ & $\begin{array}{l}19.12 .69- \\
21.12 .69\end{array}$ & $\leftarrow 3.2 a$ & $\begin{array}{l}3.12 .69- \\
9.12 .69\end{array}$ & $\begin{array}{l}10 \cdot 12 \cdot 69- \\
12.12 .69\end{array}$ \\
\hline
\end{tabular}


it was only practicable to observe the blackbirds. Predation by the other species was deduced from an examination of the baits at frequent intervals.

TABLE 3

Training experiments: grand totals of baits taken from 1:1 populations by blackbirds, housesparrows ${ }^{*}$ ) and "small birds" $(\dagger)$. The estimated numbers of birds involved are given in parentheses

\begin{tabular}{|c|c|c|c|c|c|c|c|c|}
\hline \multirow[b]{2}{*}{$\begin{array}{l}\text { Preliminary } \\
\text { experiment }\end{array}$} & \multicolumn{4}{|c|}{$\begin{array}{l}\text { Brown-trained } \\
\text { (Numbers taken) }\end{array}$} & \multicolumn{4}{|c|}{$\begin{array}{l}\text { Green-trained } \\
\text { (Numbers taken) }\end{array}$} \\
\hline & $\begin{array}{c}\text { Expt. } \\
(b)\end{array}$ & $\begin{array}{c}\text { Green } \\
52 \\
110\end{array}$ & $\begin{array}{c}\text { Brown } \\
103 \\
254\end{array}$ & $\underset{(\text { many }) \dagger}{(8+)}$ & $\begin{array}{r}\text { Expt. } \\
\leftarrow \quad(a)\end{array}$ & $\begin{array}{c}\text { Green } \\
314 \\
-\end{array}$ & $\begin{array}{c}\text { Brown } \\
98 \\
-\end{array}$ & $\stackrel{(8+)}{-}$ \\
\hline \multirow[t]{2}{*}{ Series 1} & 1.1 & 1 & 65 & (2) & 1.2 & 26 & 0 & $(2)$ \\
\hline & 1.3 & 0 & 14 & (1) & 1.4 & 55 & 0 & (2) \\
\hline \multirow[t]{3}{*}{ Series 2} & 2.1 & 0 & 111 & (4) & 2.2 & 92 & 0 & (2) \\
\hline & 2.3 & $\begin{array}{l}0 \\
0\end{array}$ & $\begin{array}{l}51 \\
31\end{array}$ & $\begin{array}{l}(4) \\
(6)^{*}\end{array}$ & 2.4 & 86 & 2 & (2) \\
\hline & 2.5 & 0 & 58 & (2) & 2.6 & 41 & 0 & (2) \\
\hline \multirow[t]{2}{*}{ Series 3} & $3.1 a$ & 0 & 71 & (2) & $\rightarrow 3.1 b$ & 129 & 41 & (2) \\
\hline & $3.2 b$ & 24 & 135 & $(4) \leftarrow$ & $\leftarrow 3.2 a$ & 106 & 0 & (4) \\
\hline
\end{tabular}

(iii) Results

Table 3 gives the grand totals of greens and browns taken from the " $1: 1$ " populations presented in the 13 experiments. Tables 4 and 5 give the daily predation for the preliminary experiment and the experiments of series 3 respectively.

\section{TABLE 4}

Preliminary experiment. Daily totals of baits taken after training with one colour alone: soil background. Figures in square brackets represent the number of visits during which the blackbirds took the specified colour in excess

(From Allen and Clarke, 1968)

\begin{tabular}{|c|c|c|c|c|c|c|}
\hline & \multirow[b]{3}{*}{ Date } & & \multicolumn{4}{|c|}{ Observed predation } \\
\hline & & \multirow{2}{*}{$\begin{array}{c}\text { Hours of } \\
\text { observation } \\
\text { (BST) }\end{array}$} & \multicolumn{2}{|c|}{$\begin{array}{c}\text { Blackbirds } \\
(8+)\end{array}$} & \multicolumn{2}{|c|}{ " Small birds" } \\
\hline & & & Green & Brown & Green & Brown \\
\hline \multirow[t]{4}{*}{ Trained with greens } & 6.9 .66 & $14.30-21.00$ & $\begin{array}{ll}52 & {[9]}\end{array}$ & $9 \quad[1]$ & - & - \\
\hline & 7.9 .66 & $11.15-19.00$ & $111[13]$ & & - & - \\
\hline & 8.9 .66 & $6.20-18.22$ & $153[32]$ & 75 & - & - \\
\hline & & Totals & 314 [54] & 98 [9] & - & - \\
\hline ined with bro & 15.10 .66 & $8.25-16.05$ & $52[8]$ & $103[20]$ & 110 & 254 \\
\hline
\end{tabular}

A total of 16 populations were presented after separate training regimes and in each case it is clear that the birds continued to eat the familiar colour. A further measure of the acquired preferences is that in ten populations the unfamiliar colour was totally neglected while in another two cases (experiments 1.1 and 2.4) predation on the unfamiliar colour was minimal. 
In other words, within each of 12 of the 16 populations there was a homogeneous response. It is legitimate, therefore, to compare statistically the observed and expected proportions taken. The deviations from an expected " $1: 1$ " ratio are all highly significant: each of the 12 results has a probability of less than 0.001 that it was due to chance.

TABLE 5

Repeat training experiments 3.1 and 3.2: daily numbers of greens and browns taken from $1: 1$ populations by blackbirds

\begin{tabular}{|c|c|c|c|c|c|}
\hline \multirow{2}{*}{$\begin{array}{c}\text { Date } \\
(1969)\end{array}$} & \multicolumn{2}{|c|}{$\begin{array}{l}\text { Experiment } 3.1 a \\
\text { Brown-trained } \\
\text { (Numbers taken) }\end{array}$} & \multirow{2}{*}{$\begin{array}{l}\longrightarrow \\
\text { Date } \\
(1969)\end{array}$} & \multicolumn{2}{|c|}{$\begin{array}{c}\text { Experiment } 3.1 b \\
\text { Green-trained } \\
\text { (Numbers taken) }\end{array}$} \\
\hline & Green & Brown & & Green & Brown \\
\hline $\begin{array}{l}28 \text { Nov } \\
29 \text { Nov } \\
30 \text { Nov }\end{array}$ & $\begin{array}{l}0 \\
0 \\
0\end{array}$ & $\begin{array}{l}24 \\
35 \\
12\end{array}$ & $\begin{array}{l}7 \mathrm{Dec} \\
8 \mathrm{Dec} \\
9 \mathrm{Dec}\end{array}$ & $\begin{array}{l}53 \\
39 \\
37\end{array}$ & $\begin{array}{r}9 \\
14 \\
18\end{array}$ \\
\hline \multirow{3}{*}{$30 \mathrm{Nov}$} & - & - & & - & - \\
\hline & 0 & 71 & & 129 & 41 \\
\hline & \multicolumn{2}{|c|}{$\begin{array}{l}\text { Experiment } 3.2 b \\
\text { Brown-trained } \\
\text { (Numbers taken) }\end{array}$} & $\longleftarrow$ & \multicolumn{2}{|c|}{$\begin{array}{c}\text { Experiment } 3.2 a \\
\text { Green-trained } \\
\text { (Numbers taken) }\end{array}$} \\
\hline $\begin{array}{c}\text { Date } \\
(1969)\end{array}$ & Green & Brown & (1969) & Green & Brown \\
\hline $19 \mathrm{Dec}$ & 5 & 56 & $10 \mathrm{Dec}$ & 35 & 0 \\
\hline $20 \mathrm{Dec}$ & 6 & 36 & $11 \mathrm{Dec}$ & 44 & 0 \\
\hline \multirow[t]{2}{*}{$21 \mathrm{Dec}$} & 13 & 43 & $12 \mathrm{Dec}$ & 27 & 0 \\
\hline & $\overline{24}$ & $\overline{135}$ & & $\overline{106}$ & $\overline{0}$ \\
\hline
\end{tabular}

In the preliminary experiment substantial numbers of the "unfamiliar" colour were taken by blackbirds after each training session (tables 3 \& 4). Nevertheless, they took more of the familiar colour than expected on the basis of random predation and this trend was highly significant despite heterogeneity in the proportions taken between visits (see figures in square brackets in table 4). After familiarisation with greens there was a significant increase in the percentage of browns taken over every five visits $(P<0.01$, Spearman's rank correlation test) suggesting that the birds were gradually learning that browns were an acceptable food. During the single day after familiarisation with browns there was no corresponding increase in the numbers of greens taken by the blackbirds but the " small birds" did show such a trend $(P<0.01)$.

The only other populations which revealed appreciable elimination of the unfamiliar varieties were those presented in experiments $3.1 b$ and $3.2 b$. This is perhaps not surprising for the birds had previously experienced both colours in experiments $3.1 a$ and $3.2 a$. Yet their preferences were clearly affected by the second training sessions for in each case they took an excess of the familiar variety on each of the 3 days of presentation of a " $1: 1$ " population (table 5). These results therefore support the finding of the preliminary experiment that the preferences produced by one session of training can be changed by a second. Although it was difficult to identify individuals there was no obvious evidence for changes in the composition in the groups of birds in the experiments. It seems a reasonable assumption, 
therefore, that individual birds underwent changes of preference. This argument is strengthened by observations in experiment 3.1 of a blackbird with two conspicuous white feathers in her tail. This bird took 24 browns, 0 greens after training with browns (experiment $3.1 a$ ) and 43 greens, 1 brown after training with greens (experiment $3.1 b$ ). In experiment $3.1 b$ there is some suggestion, in common with the preliminary experiment, that the tendency to take the unfamiliar colour increased with time $(P<0.05$, Spearman's rank correlation test, for the proportions taken over every three visits). There was no such statistically significant trend in experiment $3.2 b$, but in both experiments there was a statistically significant difference between the proportions taken on the first and last days after the second training session $\left(\chi_{(1)}^{2}=5.445, P<0.02\right.$ for experiment $3.1 b ; \chi_{(1)}^{2}=5.057$, $\mathrm{P}<0.05$ for experiment $3.2 b$ ) while the differences between other combinations of days were insignificant.

\section{Discussion}

While all the above experiments demonstrate the striking effects of training, the results of the repeat experiments seem to be more explicit than those of the preliminary study. This discrepancy could be due to differences in the stability of the compositions of the groups of birds involved in the two studies. In the repeat experiments the groups of blackbirds appeared to remain relatively stable and confined to those birds with territories in the immediate vicinity of the plots. Every bird seen feeding on the " $1: 1$ " populations was likely to have been exposed to the training regime. On the other hand, the habitat of the preliminary experiment supported a higher density of blackbirds and it seemed likely that new individuals were finding the experimental population throughout the period of study. Consequently some of the birds seen at the " $1: 1$ " populations may have eaten few, or even none, of the baits offered during training and this might explain why some birds took substantial numbers of unfamiliar baits per visit.

Blackbirds generally take more browns than expected on the basis of random predation (Allen, 1972) and it might be argued that this preference alone accounts for the results obtained after familiarisation with this colour. However, data from experiments described in Allen (1974) render this possibility unlikely. The presentation of populations with browns nine times as common as greens gave results for untrained blackbirds (plus one songthrush, Turdus philomelos) on six separate occasions (Table 18, Allen, 1974). The grand totals for the baits taken by these birds were 13 greens and 2602 browns, a ratio of about $1: 200$. In the brown-training experiments (neglecting the preliminary experiment and $3.2 b$, both of which involved an extra previous training session), 1 green and 370 browns were taken. The proportion of greens to browns taken from the " $1: 1$ " populations after training was therefore almost twice as great as in the specified " $9: 1$ " experiments. Yet, in the latter, browns were presented in relatively greater numbers. It is therefore reasonable to conclude that brown training does in fact reinforce any natural preference for this colour.

The repeatability of the training experiments is lent further weight by some similar work, using green and brown lard-and-flour baits, done at Liverpool by Sister S. Shutt (personal communication). She fed blackbirds 
(no other birds were involved) on green pellets for a week, using a background of red tiles. A population of 20 browns and 20 greens was then presented. Eaten baits were not replaced and only two blackbirds were noted feeding. On the first day 17 greens and one brown were taken and on the next, only greens. On each of the succeeding 2 days the male blackbird was the first to visit the baits and he took greens alone. Confronted with a scarcity of the preferred colour, the female then started to eat browns. Similar results for wild passerine birds have also been obtained by Oates and others (quoted by Cook, 1971, pp. 87-88). This time the prey were red and yellow lard-and-flour pellets and they were presented on a lawn in populations of 49 and at a density of one per square foot. Predators were housesparrows, blackbirds and starlings (Sturnus vulgaris). After 4 days of training on one colour, both types were presented for another 4 days in proportions of 90,70 or 50 per cent of the conditioning colour. In 10 out of 12 trials a relative excess of the conditioned colour was taken. As in my data, there was a suggestion that the tendency to remove the familiar colour declines with time. The elegant work of Croze (1970) shows that wild carrion crows (Corvus corone) also tend to search for familiar artificial polymorphic prey, in this case painted sea-shells covering pieces of meat. It seems probable, then, that the effect described in this paper is repeatable with wild passerine birds. Similar behaviour has been reported for captive birds (Rabinowitch, 1968; Dawkins, 1971 $a$, b; Manly et al., 1972), captive fish (Beukema, 1968), and captive mammals hunting by scent (Soan and Clarke, 1973).

The training experiments therefore support Tinbergen's original contention that wild birds can build up searching images for prey and may consequently overlook new species, even if these become relatively common. Or, if the two colours were morphs of the same species, then we have a mechanism capable of maintaining the polymorphism. The experimental design can be likened to a dimorphic population where one morph is very rare. In such circumstances predators are likely to encounter a number of the common morph before any of the rare ones; the training sessions in my experiments ensured that this happened to the majority (or all) of the predators involved. The outcome of experiments in which untrained birds are given the chance to form searching images for a rare colour is discussed in Allen (1974).

The experiments still leave a number of questions unanswered, for example, with regard to the persistence of the searching images. Presumably, the longer the period of training, the "stronger" the searching images are likely to be. Neither do the experiments tell us anything about the specificity of the searching images; this will be discussed in a future article. The most important point now is whether sightdependent predators can be trained to search for a particular morph of a natural polymorphic species. Future work should be directed towards answering this question.

Acknowledgments. - I thank in particular my supervisor, Professor Bryan Clarke, for his helpful advice. He also constructively criticised the manuscript, as did Dr D. T. Parkin and Mr D. A. S. Smith. I thank Professor J. M. Mitchison and Professor P. M. B. Walker for providing facilities at the Department of Zoology, University of Edinburgh. The Science Research Council provided financial support. Finally, I thank all those people who allowed me to use their land for my experiments. 


\section{References}

ALleN, J. A. 1972. Apostatic selection: the responses of wild passerines to artificial polymorphic prey. Ph.D. thesis, University of Edinburgh.

ALlEN, J. A. 1974. Further evidence for apostatic selection by wild passerine birds: $9: 1$ experiments. (In preparation.)

ALlEN, J. A., AND CLARKE, B. C. 1968. Evidence for apostatic selection by wild passerines. Nature, 220, 501-502.

Beukema, J. J. 1968. Predation by the three-spined stickleback (Gasterosteus aculeatus L.): the influence of hunger and experience. Behaviour, 31, 1-127.

BYRNE, O. R. 1967. Polymorphism in the Australian Acrididae. 1. Inheritance of colour patterns in the plague locust Chortoicetes terminifera. Heredity, 22, 561-563.

CAIN A. J., AND SHEPPARD, P. M. 1954. Natural selection in Cepaea. Genetics, 39, 89-116.

CARTER, M. A. 1967. Selection in mixed colonies of Cepaea nemoralis and Cepaea hortensis. Heredity, 22, 117-139.

CLARKE, B. 1962a. Balanced polymorphism and the diversity of sympatric species. In Taxonomy and Geography, ed. D. Nichols. Systematics Association, Oxford.

CLARKE, B. 1962b. Natural selection in mixed populations of two polymorphic snails. Heredity, 17, 319-345.

CLARKE, B. 1969. The evidence for apostatic selection. Heredity, 24, 347-352.

ClARKE, B., AND O'DONALD, P. 1964. Frequency-dependent selection. Heredity, 19, 201-206. COOK, L. M. 1971. Coefficients of Natural Selection. Hutchinson, London.

CROZE, H. T. 1970. Searching image in carrion crows. Z. Tierpsychol., 5, 1-85.

DAWkins, M. 1971a. Perceptual changes in chicks: another look at the "search image" concept. Anim. Behav., 19, 566-574.

DAWKINs, M. 1971b. Shifts of "attention" in chicks during feeding. Anim. Behav., 19, 575-582.

DEN BOER, M. H. 1971. A colour polymorphism in caterpillars of Bupalus piniarius (L) (Lepidoptera: Geometridae). Neth. 7. Zool., 21, 61-116.

Fisher, R. A., AND YATES, F. 1963. Statistical Tables for Biological, Agricultural and Medical Research (6th ed.). Oliver and Boyd, London.

GIBB, J. A. 1962. L. Tinbergen's hypothesis on the role of specific search images. Ibis, $104,106-111$.

GREENWOOD, J. J. D. 1969. Apostatic selection and population density. Heredity, 24, $157-161$.

HALDANE, J. B. S. 1955. The biochemistry of heterosis and the stabilization of polymorphism. Proc. R. Soc., B, 144, 217-220.

haldane, J. B. S., AND JaYAKar, s. D. 1963. Polymorphism due to selection depending on the composition of the population. 7. Genet., 58, 318-323.

LI, c. c. 1962. On " reflexive selection". Science, 136, 1055.

MANLY, F. J., MILlER, P., AND COOK, L. M. 1972. Analysis of a selective predation experiment. Am. Nat., 106, 719-736.

MOMENT, G. B. 1962. Reflexive selection: a possible answer to an old puzzle. Science, 136, $262-263$.

MOOK, J. H., MOOK, L. J., AND HEIKENs, H. s. 1960. Further evidence for the role of " searching images" in the hunting behaviour of titmice. Arch. Néerl. Zool., 13, 448-465.

The Munsell Book of Color (1966). Munsell Color Co. Inc., Baltimore.

MURDOCH, w. w. 1969. Switching in general predators: experiments on predator specificity and stability of prey populations. Ecol. Monogr., 39, 335-354.

MURTON, R. K. 1971. The significance of specific search image in the feeding behaviour of the wood pigeon. Behaviour, 40, 10-42.

OGILviE, P. W., AND OWEN, D. F. 1964. Colour change and polymorphism in Chameleo bitaeniatus. Nature, 202, 209-210.

OWEN, D. F. 1963. Polymorphism and population density in the African land snail Limicolaria martensiana. Science, 140, 666-667.

owen, D. F. 1966. Animal Ecology in Tropical Africa. Oliver and Boyd, London.

POPнAм, E. J. 1941. The variation of the colour of certain species of Arctocorisa (Hemiptera, Corixidae) and its significance. Proc. Zool. Soc. Lond., 111, 135-172.

POPHAM, E. J. 1942. Further experimental studies on the selective action of predators. Proc. Zool. Soc. London, 112, 105-117.

poulton, E. B. 1884. Notes upon, or suggested by, the colours, markings, and protective attitudes of certain lepidopterous larvae and pupae, and of phytophagous hymenopterous larvae. Trans. ent. Soc. Lond. (1884), 15-56. 
RABINOWITCH, V. E. 1968. The role of experience in the development of food preferences in gull chicks. Anim. Behav., 16, 425-428.

REIGHARD, J. 1908. Warning coloration in coral-reef fishes. Publs. Carnegie Instn., 103, 257-325.

Resnick, L. E., AND JAmeson, D. L. 1963. Color polymorphism in Pacific tree frogs. Science, $142,1081-1082$.

ROYAMA, T. 1970. Factors governing the hunting behaviour and food selection of the great tit (Parus major L.). F. Anim. Ecol., 39, 619-668.

schiøтz, A. 1971. The supergenus Hyperolius viridiflavus (Anura). Vidensk. Meddr. dansk. naturh. Foren., 134, 21-76.

sMith, D. A. s. 1971. Polymorphism and population density in Donax rugosus (Lamellibranchiata: Donacidae). F. Zool. Lond., 164, 429-442.

SMITH, J. N. M., AND DAWKINs, R. 1971. The hunting behaviour of individual great tits in relation to spatial variations in their food density. Anim. Behav., 19, 695-706.

sNow, D. w. 1958. A Study of Blackbirds. Allen and Unwin, London.

SOAN, I. D., AND CLARKE, B. 1973. Evidence for apostatic selection by predators using olfactory cues. Nature, 241, 62-64.

TINBERGEN, L. 1960. The natural control of insects in pine woods. 1. Factors influencing the intensity of predation by songbirds. Arch. Néerl. Zool., 13, 265-343.

TURNER, E. R. A. 1961. Survival values of different methods of camouflage as shown in a model population. Proc. Zool. Soc. Lond., 136, 273-283.

uExkull, J. von. 1934. Streifzüge durch die Umwelten von Tieren und Menschen. Springer, Berlin.

WRIGHT, s. 1948. On the roles of directed and random changes in gene frequency in the genetics of natural populations. Evolution, 2, 279-294. 